\title{
New trends in the relationship between psychoanalysis and psychiatry
}

\author{
Michel Botbol
}

Professor of Child and Adolescent Psychiatry, University of Western Brittany and Brest University Hospital, France:

email botbolmichel@orange.fr

(c) The Author 2018. This is an Open Access article, distributed under the terms of the Creative Commons Attribution-

NonCommerical-NoDerivatives licence http://creativecommons. org/licenses/by-nc-nd/4.0/), which permits non-commercial re-use, perits non-conmercial re-use, eproduction in any medium, provided the original work is unaltered and is properly cited. The written permission of Cambridge University Press must be obtained for commercial re-use or in order to create a derivative work.
Created in the early 1890s by Sigmund Freud, a Viennese neurologist, psychoanalysis is a set of theories and therapeutic techniques designed to deal with mental disorders. Aiming primarily to explain 'scientifically' the neurological-like symptoms with neither apparent organic causes nor relevant neurological compatibility, psychoanalysis has been controversial from its beginning as it is built on two conflictual objectives:

(a) to draw a line between organic (neurological) and non-organic (psychiatric) neurologicallike illnesses;

(b) to propose a scientific theory (Freud calls it metapsychology) on the psychological mechanisms underlying these non-organic illnesses to replace the previous metaphysical speculations concerning their causes and mechanisms; Freud clearly expresses his scientific ambition when he writes that the main theoretical objective of his psychoanalytical project is 'to translate metaphysics into metapsychology' (Freud, 1901). In this project, he builds upon Charcot's theories about hysteria (Charcot \& Richer, 1887), surmising 'that traumatic shock could be at the root of the religious phenomena and sacrifices' (Bonomi, 2017).

Theoretical investigation in relation to neurological-like phenomena was the main leverage Freud used to reach these two objectives; this does not mean that Freud's psychoanalysis was interested only in neurological-like illnesses. Rather, it means that its theoretical journey began around the attempt to solve scientifically the problems raised by this type of disorder. Freud's work rapidly extended its scope to other types of illnesses as well: i.e. non-neurological-like illnesses such as 'neurosis', 'melancholia' and, later, psychosis. It is often forgotten that in formulating his understanding of each of these illnesses or symptoms, he tried hard to remain consistent with the scientific objectives and methodology that were becoming dominant in medicine at large: for example to expose these theoretical assumptions to the clinical facts.

From its beginning, psychoanalysis was created as a 'work in progress' and not as a final product. This principle is obvious in Freud's writings as illustrated by the evolution of Freud's theories; he had to constantly re-elaborate to integrate new clinical observations that his previous conceptions were not able to explain rationally.

The aim of psychoanalysis was then to challenge both the neurological and the psychiatric models of that time, bringing significant improvement to their scientific approaches. The new perspective it brought had, in itself, valuable consequences on the humanisation of neuropsychiatric care: Psychoanalysis was among the first theoretical perspectives of the modern time to consider those who were suffering from mental disorders as full subjects; as shown by G. Swain (Swain, 1977) and Marcel Gauchet (Gauchet \& Swain, 1980) this idea was at the centre of Pinel's 'enlightenment' psychiatry. Psychoanalysis in psychiatry was then the avant-garde of clinical and theoretical practices in mental health, leading to important progresses in the diffusion and use of institutional treatments (milieu therapy, 'institutional psychotherapy'), psychotherapies for psychiatric patients and the emergence of community carers, at least in the better resourced countries. In France, for example, this is remembered as the golden age for psychoanalysis in psychiatric institutions and services. In particular, after the Second World War, there was a progressive development of the 'secteur' model, which is grounded on a social psychiatry perspective infiltrated by psychoanalytical ideas, and was very influential in continental psychiatry at that time.

During the 1950s, this model began to be challenged by the development of biological psychiatry which was stimulated by the discovery of new psychiatric medications. This challenge led to a diminution of the influence of psychoanalysis in psychiatry at a speed depending on the context (economic, social, political, cultural, scientific); i.e. this evolution was quicker in the UK than in France or Germany.

The success of the movement towards evidencebased medicine in dominant academic psychiatry and in research gave a near fatal blow to psychoanalysis in psychiatry. This is to such an extent that psychoanalysis has nearly disappeared from the clinical practice and from the psychiatric publications in most English-speaking countries and most academically influential institutions. Let us also remember that until 2001 there was no World Psychiatric Association section that referred to psychoanalysis, in spite of the Association's claim to be global and integrative. It was only after a long, and sometime difficult, process that psychoanalysis finally got some recognition in this context through the Psychoanalysis in Psychiatry (PIP) section that I contributed to creating together with S. D. Kipman, A. Tasman, B. Martindale and K. Pulkanen. Significantly, the development of the evidencebased outcome studies in psychoanalytic psychotherapy was helpful in that process, even if the 
results were still ambiguous at that time (Luborsky et al, 1975; Smith et al, 1980; Parloff, 1982). The replication of these outcome studies and the dissemination of some of them (Fonagy \& Roth, 2004; Fonagy et al, 2005; Glass, 2008; Leichsenring et al, 2008) was instrumental in supporting the creation of PIP and other similar initiatives in national and international scientific societies.

Indeed, in the past decade we have been witnessing a new era in this regard and we are at the crossroads of two promising converging evolutions:

(a) From the neuroscience perspective: the development of the capacity to be less reductionist and to integrate in its scope finer-grained natural, relational or psychological aspects (i.e. empathy, emotions, subjectivity and intersubjectivity) (Berthoz, 2014), allowing for the consideration of more complex person-centred dimensions (Mezzich et al, 2010).

(b) From the psychoanalysis perspective: the development of the capacity to face and address the three main criticisms that are still diminishing its impact in psychiatry:

(i) doubts about the therapeutic effectiveness of psychoanalysis and psychoanalytic psychotherapies;

(ii) doubts about the applicability of psychoanalytic approaches to major psychiatric conditions because of the nature of their psychopathology;

(iii) doubts about the validity of psychoanalytic, psychopathological assumptions in scientific terms.

Most psychoanalytic organisations consider that addressing these three problems is their most important challenge today. This thematic issue on Psychoanalysis in Psychiatry gives us the opportunity to illustrate this recent evolution by using examples of the commitment shown in addressing each of these three problems.

The issue of therapeutic effectiveness is directly or implicitly at the centre of Mark Solms' paper in which he presents a comprehensive and easy-to-understand overview of how psychoanalysis works and how it can be an evidencebased therapeutic tool in psychiatry. Miguel Angel Gonzales Torres describes new forms of psychoanalytic psychotherapy that are specifically adapted to the treatment of personality disorders and to contexts within which classical psychoanalytic approaches are difficult or impossible to implement. He also shows how the use of these new forms of treatment is evidence based. Cesar Alfonso exposes the vivid experience of the program of psychoanalytic psychotherapy education he has developed in emerging countries in South East Asia, with an impressive success rate record. Finally, I will describe the situation in France, where psychoanalysis has long been very influential in psychiatry and other fields and where, despite the current tensions, psychoanalysis continues to be one of the elements taken into account when considering the validity of research and when thinking about issues of social significance, including psychiatry.

\section{References}

Berthoz A. (2014) Une théorie spatiale de la difference entre la sympathie et les processus de l'empathie [A spatial theory of the difference between sympathy and empathic processes]. In L'empathie au Carrefour de la science et de la Clinique [Empathy at the Crossroad of Science and Clinics] (eds M. Botbol, N. Garret \& A. Besse), pp. 77-99. Doin.

Bonomi C. (2017) The Cut and the Building of Psychoanalysis, Vol II. Taylor \& Francis.

Charcot J.-M. \& Richer P. (1887) Les démoniaques dans l'art [The possessed in art]. Delahaye et Lecrosnier.

Fonagy P. \& Roth A. (2004) What Works for Whom? A Critical Review of Psychotherapy Research. Guildford Press.

Fonagy P., Roth A. \& Higgit A. (2005) Psychodynamic psychotherapies: evidence-based practice and clinical wisdom. Bulletin of the Meninger Clinic, 69, 1-58.

Freud S. (1901) Psychopathologie de la vie quotidienne [Psychopathology of everyday life]. Payot.

Gauchet M. \& Swain G. (1980) La pratique de l'esprit humain L'institution asilaire et la révolution démocratique [The practice of human mind: Asylum and democratic revolution]. Gallimard.

Glass R. M. (2008) Psychodynamic psychotherapy and research evidence: Bambi survives Godzilla? JAMA, 300, 1551-1565.

Leichsenring F., Rabung S. \& Leibring E. (2008) The effectiveness of long term psychodynamic psychotherapy: a meta-analysis. JAMA, $300,1551-1565$

Luborsky L., Singer B. \& Luborsky L. (1975) Comparative studies of psychotherapies: is it true that everyone has won and all must have prizes? Archives of General Psychiatry, 32, 995-1008.

Mezzich J. E., Salloum I. M., Cloninger R. C., et al (2010)

Person-centered integrative diagnosis: conceptual bases and structural model. Canadian Journal of Psychiatry, 55, 701-708.

Parloff M. B. (1982) Psychotherapy research evidence and reimbursement decision: Bambi meets Godzilla. The American Journal of Psychiatry, 139, 718-727.

Smith M. L. S., Glass G. V. \& Miller T. I. (1980) The Benefits of Psychotherapy. Johns Hopkins University Press.

Swain G. (1977) Le sujet de la folie: la naissance de la psychiatrie [The subject of madness: the birth of psychiatry]. Privat. 